\title{
Performance Indicators For Grid-Connected PV Systems: A Case Study In Casablanca, Morocco
}

\author{
Amine Haibaoui ${ }^{1,2}$, Bouchaib Hartiti ${ }^{1 *}$, Abderrazzak Elamim $^{1}$, Mehdi Karami ${ }^{2}$, \\ Abderraouf Ridah ${ }^{2}$ \\ ${ }^{I}$ MEE \& DD Group, University Hassan ll Casablanca FSTM, BP 146 Mohammedia 20650, Morocco \\ *Senior Assoc, ICTP, UNESCO, Trieste, Italy \\ ${ }^{2}$ LIMAT Laboratory, Department of Physics FSB, Hassan II Casablanca University B.P 7955, Casablanca, \\ Morocco
}

\begin{abstract}
The main goal of this paper is to compare a one year performance of $5.94 \mathrm{KWp}$ grid-connected $\mathrm{PV}$ module technology systems, constituted by three types of photovoltaic solar panels (Monocrystalline ( $\mathrm{mc}$-Si) $(2.04 \mathrm{KWp})$, polycrystalline ( $\mathrm{pc}-\mathrm{Si})(2.04 \mathrm{KWp})$ and amorphous ( $\mathrm{a}-\mathrm{Si})(1.86 \mathrm{KWp})$ )-silicon installed on the roof of the faculty of science Ben M'sik Casablanca. The study is based on the data collected along 2 years (2015-2016) about energy production. The elements of performance evaluated monthly and annually include: energy output, system efficiency, reference yield, final yield, performance ratio, annual capacity factor and CO2 emissions avoided. The investigation of the annual: productivity $\left(E_{A C, Y}\right)$, system efficiency $\left(\eta_{s y s, Y}\right)$, performance ratio $\left(P_{R}\right)$, capacity factor (CF) and amount of CO2 emissions avoided for a-Si are found as $2941.15 \mathrm{KWh}, 7.21 \%, 73.1 \%$, $18.05 \%$ and 1.765 tons respectively. $E_{A C, Y}, \eta_{s y s, Y}, P_{R}, C F$ and amount of CO2 emissions avoided for pc-Si are found as $3331.15 \mathrm{KWh}, 11.4 \%, 75.6 \%, 18.64 \%$ and 1.999tons respectively. Mc-Si installation exhibits slightly higher values of $E_{A C, Y}, \eta_{\text {sys }, Y}, P_{R}, C F$ and amount of CO2 emissions avoided which are $3370.89 \mathrm{KWh}, 11.7 \%$, $76.7 \%, 18.86 \%$ and 2.023 tons respectively. The results show that $\mathrm{mc}$-Si system presents the best performance followed by pc-Si and by a-Si. In addition, a developed study was carried out to establish the relation between the efficiency and temperature, performance ratios and radiation, in order to know the behavior of each technology for each period of the year and for the whole year. Without forgetting a comparison of all results found with the previous studies in different locations.
\end{abstract}

Keywords: grid-connected, silicon, monocrystalline, polycrystalline, amorphous, performance analysis.

\section{Introduction}

The energy crisis marked by a surge in oil prices and the imperatives of sustainable development make renewable energies an alternative that are now attracting researchers from several countries, knowing that the total energy consumption of the world reached 19,710 billion $\mathrm{kW}$ h/year in 2016 [1].

Non-oil-producer, Morocco is also concerned by this crisis. To get along with this, the new energy policy focuses on the use of renewable energies in particular, solar energy. In this way comes the energy transition strategy adopted by Morocco, which is made to increase the share of renewable energies from $42 \%$ installed capacity by 2020 to $52 \%$ by 2030 . Morocco will have to develop (between 2016 and 2030) an additional capacity of 10100MW from renewable energies, of which solar will reach $4560 \mathrm{MW}$ [2]. The conversion of solar energy to another useful energy can be done by a lot of solar systems [3]. One of these solar systems is used to produce the electricity based on photovoltaic system (PV). This latter system can be used in two ways, in an isolated cites [4] or in connected to the power grid [5]. The photovoltaic effect is a physical phenomenon peculiar to some materials called semiconductors which produce electricity when exposed to sunlight. These PV materials include several types of PV technologies such as Crystalline Silicon (monocrystalline and polycrystalline), thin films (amorphous silicon (a-Si), cadmium Telluride (CdTe) or copper-indium gallium-selenide (CIGS)), Multi-junction cells and concentrating photovoltaics (CPV). Silicon cells make up the majority of the market, with an estimation of $90 \%$ of market share while thin films constitute less than $10 \%$ [6]. Silicon solar cells efficiency has been tested in the laboratory at standard test conditions (STC) $\left(25^{\circ} \mathrm{C}, 1000 \mathrm{~W} / \mathrm{m} 2\right.$ and AM: 1.5$)$ and it is close to $24.4 \%$ for monocrystalline, $19.8 \%$ for polycrystalline and $10.2 \%$ for amorphous $[7,8,9]$. However, the increase in efficiency takes an exponential pace of about $0.3 \%$ per year due to the considerable technology progress [6].

As it is known, PV panels with several manufacturing technologies are produced today. These PV panels can have the same maximum power at STC, but the technical information provided from standard test conditions may never occur in practice [10], not only due to spectral reactions, temperature coefficients, voltage and current values which are differents, but also to their reactions to environmental factors like radiation, temperature and wind speed. The measurements on-site are the most accurate method to determine the 
performance of various designs under actual operating environments and the obtaining of reliable data for evaluation [11]. Several research works, in different places in the world, about the performance and characteristics of grid connected systems have been found in the literature [12, 13, 14, 15] for example $\mathrm{Li}$ and al presented a study of a grid-connected PV system in Hong Kong, and showed that the energy payback period was estimated to be 8.9 years [16]. Canete et al. analysed 4 different module technologies, like a-Si, microcrystalline silicon, $\mathrm{Cd}$ and Amount of incoming solar radiation for a year in Spain and reported that thin-films were more productive than polycrystalline modules [17]. This work is part of the "PROPRE.MA" project, proposed by the Faculty of Science Semlalia Marrakech (FSSM) and financed by IRESEN (02/2014-01/2016). The primary goal of "PROPRE.MA" consists to address grid-connected PV yield maps for the whole country with ground calibration on 20 identical plants installed in partner institutional buildings located in 20 different Moroccan cities. Each plant consists of three grid-connected PV systems using monocrystalline, polycrystalline and amorphous silicon technologies. A monitoring system has been constructed to evaluate the produced energy by PV systems and investigate the effect of meteorological conditions on their performance [18].

The main purpose of this paper is to evaluate the performance of $5.94 \mathrm{KWp}$ system constituted of three technologies named a-Si, pc-Si and mc-Si for a 12 months period under Casablanca climate conditions. The collected data along 2 years and PVGIS solar radiation estimate tool have been used for this comparison in order to investigate which one of these technologies is the most efficient and affordable.

\subsection{Description of location:}

The 5.94 KWp grid-connected PV systems are installed on the roof of the Faculty of sciences Ben M'Sik Casablanca with a latitude of $33^{\circ} 33^{\prime} 56.33 \|$ North and a longitude $7^{\circ} 32^{\prime} 29.22 \|$ West (see Figure1). Casablanca located in the central western part of the country bordering the Atlantic Ocean, with a latitude of $33^{\circ} 35.2986^{\prime}$ North and a longitude $7^{\circ} 36.6828^{\prime} \mathrm{West}$, at $80 \mathrm{~km}$ south of Rabat, the administrative capital. Casablanca is the largest city in Morocco with an area of about $149 \mathrm{~m}^{2}$, one of the most important cities in Africa, both economically and demographically (see Figure2).

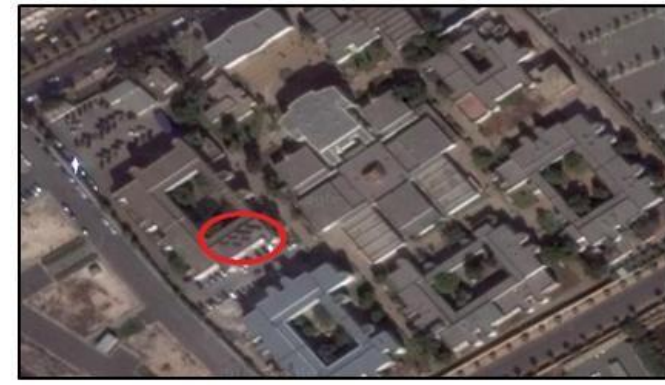

Figure1: .Location of roof by Google Earth.

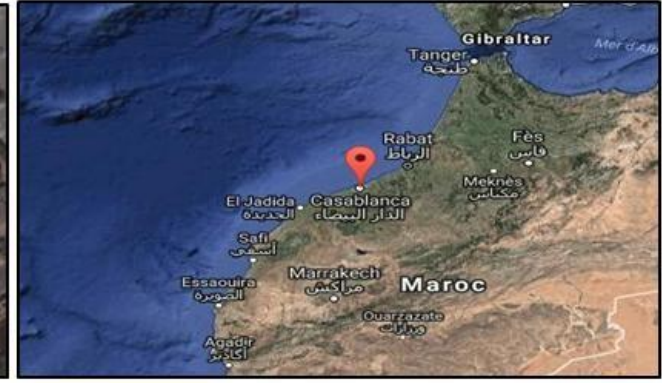

Figure2: .Location of Casablanca city by Google Earth

\section{Solar PV plant}

The grid-connected PV system includes 12 amorphous silicon thin-film panels (a-Si), each one with $155 \mathrm{Wp}, 8$ polycrystalline panels (pc-Si), and 8 monocrystalline panels (mc-Si), each one with $255 \mathrm{Wp}$. PV panel power were placed on the roof of FSBM in Casablanca. A-Si modular series was installed in double row, polycrystalline and mono-crystalline panels in single row. The PV modules are mounted facing south with a near to latitude tilt angle $\left(30^{\circ}\right)$, supposed close to the optimal value to provide a maximum annual yield. The appearance of PV systems on the roof surface is given in Figure 3. Every module series was connected to a different inverter with conducting wire. Electrical energy produced by PV modules and converted into AC currency $(230 \mathrm{~V}$ and 50 $\mathrm{Hz}$ ) via an inverter was transferred to power plant connected to FSBM building. The inverters used in the system are shown in Fig 4.

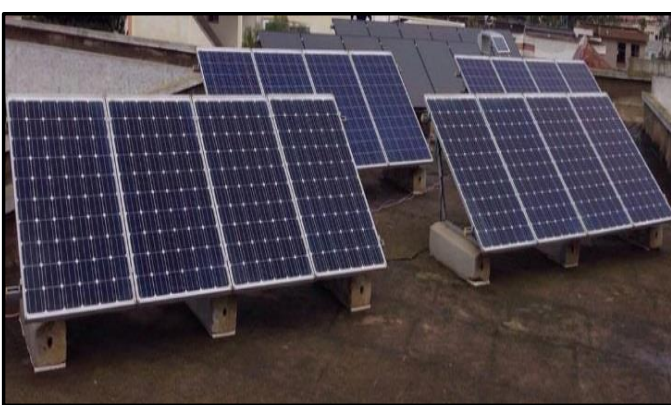

Figure 3: FSBM PV systems

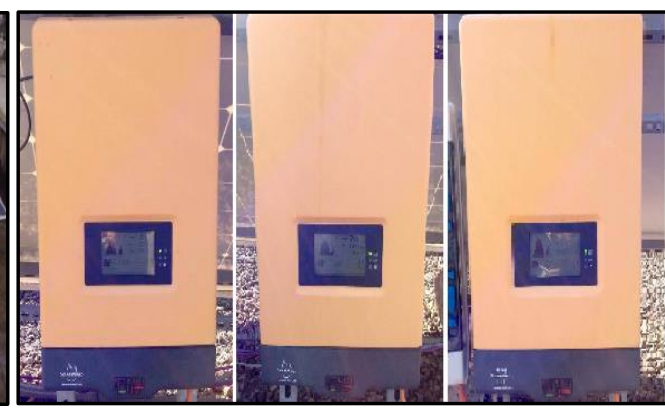

Figure 4: Connected inverters on FSBM 


\subsection{PV panels:}

Three PV panel types, 12 NEXPOWER Solar a-Si thin film panels XTREM+ (NT -155AF) were connected in series whose size is $1412 \times 1112 \times 35 \mathrm{~mm}$ and total surface is $1.84 \mathrm{~m}^{2}$. The module weight is $19.5 \mathrm{~kg}$. 8 polycrystalline panels (SUNMODULE plus SW 255 poly) are used at this study. Physical properties of this PV panel are $18 \mathrm{~kg}$ weight and $1675 \times 1001 \times 33 \mathrm{~mm}$ module size. 8 monocrystalline (SUNMODULE Plus SW 255 mono) whose size is $1675 \times 1001 \times 33 \mathrm{~mm}$ and weight is $21.2 \mathrm{~kg}$. Electrical properties of these $3 \mathrm{PV}$ modules are shown at Table 1

\begin{tabular}{|c|c|c|c|}
\hline & System-1 & System-2 & System-3 \\
\hline Trademark & NEXPOWER & \multicolumn{2}{|c|}{ SOLARWORLD } \\
\hline Model & XTREM+(NT -155AF) & $\begin{array}{l}\text { SUNMODULE plus SW } 255 \\
\text { poly }\end{array}$ & $\begin{array}{l}\text { SUNMODULE Plus SW } 255 \\
\text { mono }\end{array}$ \\
\hline Solar cell & Thin film (a-Si) & Poly crystalline & Mono crystalline \\
\hline Maximum power at STC & $155 \mathrm{~W}_{\mathrm{p}}$ & $255 \mathrm{~W}_{\mathrm{p}}$ & $255 \mathrm{~W}_{\mathrm{p}}$ \\
\hline Maximum power point voltage $\left(V_{m p}\right)$ & $65.9 \mathrm{~V}$ & $30.9 \mathrm{~V}$ & $31.4 \mathrm{~V}$ \\
\hline Maximum power point current $\left(I_{m p}\right)$ & $2.43 \mathrm{~A}$ & $8.32 \mathrm{~A}$ & $8.15 \mathrm{~A}$ \\
\hline Open circuit voltage $\left(V_{o c}\right)$ & $85.5 \mathrm{~V}$ & $38 \mathrm{~V}$ & $37.8 \mathrm{~V}$ \\
\hline Short circuit current $\left(I_{\text {sc }}\right)$ & $2.56 \mathrm{~A}$ & $8.88 \mathrm{~A}$ & $8.66 \mathrm{~A}$ \\
\hline Module efficiency & $9.9 \%$ & $15.21 \%$ & $15.51 \%$ \\
\hline Length & $1412 \mathrm{~mm}$ & \multicolumn{2}{|c|}{$1675 \mathrm{~mm}$} \\
\hline Width & $1112 \mathrm{~mm}$ & \multicolumn{2}{|c|}{$1001 \mathrm{~mm}$} \\
\hline Weight & $19.5 \mathrm{~kg}$ & $18 \mathrm{~kg}$ & $21.2 \mathrm{~kg}$ \\
\hline Temperature Coefficient $\left(P_{\max }\right)$ & $-0.28 \% /{ }^{\circ} \mathrm{C}$ & $-0.41 \% /{ }^{\circ} \mathrm{C}$ & $-0.45 \% /{ }^{\circ} \mathrm{C}$ \\
\hline
\end{tabular}

Table 1: Specifications of PV panels used in the power plants.

\subsection{Inverter Sunnyboy 2000HF-30:}

In this study, 3 Sunnyboy 2000 HF-30 were used. Each plant employs an inverter independently. The efficiency achieved by $2100 \mathrm{~W}$ DC power and $2000 \mathrm{~W}$ nominal AC power inverters was $96.3 \%$. It is possible to follow monthly and total production information by software adapted to the inverters, whose size is $348 \times 580 \times 145 \mathrm{~mm}$ and it weighs about $17 \mathrm{~kg}$.

Technical properties of Sunnyboy 2000HF-30 inverter are shown in Table 2.

\begin{tabular}{|c|c|c|c|c|c|}
\hline \multicolumn{6}{|c|}{ Technical data } \\
\hline \multirow[t]{7}{*}{ Input (DC) } & Max.DC power (@ cos $\phi=1)$ & $2100 \mathrm{~W}$ & \multirow[t]{7}{*}{ Output (AC) } & AC nominal power (@230 V,50 Hz) & $2000 \mathrm{~W}$ \\
\hline & Max. DC voltage & $700 \mathrm{~V}$ & & Max. AC apparent power & $2000 \mathrm{VA}$ \\
\hline & MPP voltage range & $175 \mathrm{~V}-560 \mathrm{~V}$ & & Nominal AC voltage; range & $\begin{array}{c}220,230,240 \mathrm{~V} \\
180-280 \mathrm{~V}\end{array}$ \\
\hline & DC nominal voltage & $530 \mathrm{~V}$ & & AC grid frequency; range & $50,60 \mathrm{~Hz} ; \pm 4.5 \mathrm{~Hz}$ \\
\hline & Min. DC voltage / start voltage & $175 \mathrm{~V} / 220 \mathrm{~V}$ & & Max. output current & $11.4 \mathrm{~A}$ \\
\hline & Max. input current / per string & $12 \mathrm{~A} / 12 \mathrm{~A}$ & & Power factor $(\cos \phi)$ & 1 \\
\hline & $\begin{array}{c}\text { Number of MPP trackers / strings } \\
\text { per MPP tracker }\end{array}$ & $1 / 2$ & & Phase conductors / connection phases & $1 / 1$ \\
\hline \multicolumn{3}{|l|}{ Efficiency } & & & $96.3 \% / 95.0 \%$ \\
\hline \multicolumn{6}{|c|}{ General data } \\
\hline \multicolumn{3}{|c|}{ Dimensions (W/H / D) in mm } & & & $348 \times 580 \times 145$ \\
\hline \multicolumn{3}{|l|}{ Weight } & & & $17 \mathrm{~kg}$ \\
\hline \multicolumn{3}{|c|}{ Operating temperature range } & & & $-25^{\circ} \mathrm{C} \ldots+60^{\circ} \mathrm{C}$ \\
\hline
\end{tabular}

Table 2: Technical characteristic of Sunnyboy 2000 HF-30 inverter.

\section{Performance analysis}

The elements used to study and evaluate the performance parameters of the three different PV systems (a-Si, pc-Si and mc-Si), include: total energy generated by the PV system $\left(\mathrm{E}_{\mathrm{AC}}\right)$, monthly and annually system efficiency $\left(\eta_{\text {sys }(m, Y)}\right)$, reference yield $\left(Y_{R}\right)$, final yield $\left(Y_{F}\right)$, performance ratio $\left(P_{R}\right)$ and capacity factor $(C F)$ which are described by IEC 61724:1998 and the international energy agency task II database on photo-voltaic power system $[19,20]$ and an environmental performance.

\subsection{Energy produced by the PV panels:}

The integration of the instantaneous values of the maximum power into the measurement interval generates the energy $\left(\mathrm{E}_{\mathrm{AC}}\right)$ [21]. Monthly generated energy is calculated with equation (1).

$$
\mathrm{E}_{\mathrm{AC}}=\int_{0}^{\mathrm{ts}} \mathrm{P}_{\mathrm{AC}} \mathrm{dt}
$$


ts is the integration period and $\mathrm{dt}$ is the duration and $\mathrm{P}_{\mathrm{AC}}$ the power of $\mathrm{AC}$ electricity output [22].

The instantaneous energy output was obtained by measuring the energy generated by the PV system after the

DC/AC conversion on 5 min intervals, like it was done by [23].

\subsection{System ef ficiency:}

Energy performance of PV systems depends on the overall efficiency of the equipment used in these systems [21]. System efficiency is calculated as the energy produced by the system to amount of radiation reflecting onto PV surface ratio. It can be calculated in yearly, monthly or even daily periods. In our study we will calculate the monthly and yearly system efficiency which is represented by the equation (2) and (3) respectively [24].

$$
\begin{aligned}
& \eta_{\text {sys, },}(\%)=\frac{E_{A C, m}}{S \times G_{o p t, m}} \\
& \eta_{s y s, Y}(\%)=\frac{E_{A C, Y}}{S \times G_{o p t, Y}}
\end{aligned}
$$

$\mathrm{E}_{\mathrm{AC}, \mathrm{m}}$ and $\mathrm{E}_{\mathrm{AC}, \mathrm{Y}}$ represents monthly and annually $\mathrm{AC}$ energy amount transferred to power plant by the system $(\mathrm{kWh})$ respectively , $\mathrm{S}$ is the total surface area of the panels $\left(\mathrm{m}^{2}\right)$ and $\mathrm{G}_{\mathrm{opt}, \mathrm{m}}$ and $\mathrm{G}_{\mathrm{opt}, \mathrm{Y}}$ monthly and annually amount of radiation reflecting onto unit area of panel surface $\left(\mathrm{kWh} / \mathrm{m}^{2}\right)$ respectively.

\subsection{Reference yield:}

The reference yield $\left(Y_{R}\right)$ represents the ratio of the total in-plane solar insolation $G_{o p t}\left(K w h / \mathrm{m}^{2}\right)$ divided by the array reference irradiance $\left(\mathrm{G}_{\mathrm{STC}}=1 \mathrm{~kW} / \mathrm{m}^{2}\right)$. It expresses a number of peak sun-hours [25]. It can be written as:

$$
Y_{R}=\frac{G_{\text {opt }}}{G_{S T C}}
$$

\subsection{Final yield:}

The final yield is defined as the annual, monthly or daily net energy generated, $\mathrm{E}_{\mathrm{AC}}$ divided by $\mathrm{P}_{\text {stc }}$, rated power of the installed PV array at standard test conditions (STC) of $1 \mathrm{~kW} / \mathrm{m}^{2}$ solar irradiance and $25^{\circ} \mathrm{C}$ cell temperature. The YF is an ideal indicator permitting the normalization of the energy produced in accordance with the system size [26-27-28]. It can be calculated using equation (5):

$$
Y_{F}=\frac{E_{A C}}{P_{S T C}}
$$

\subsection{Performance ratio:}

The performance ratio $P_{R}$ is an indicator that normalizes the energy fed to grid with respect to the received irradiance. $\mathrm{P}_{\mathrm{R}}$ is used to compare and evaluate performances of $\mathrm{PV}$ systems in different regions and at different times. $\mathrm{P}_{\mathrm{R}}$ is calculated using equation (6): [23, 29].

$$
\mathrm{P}_{R}(\%)=\frac{\mathrm{Y}_{\mathrm{F}}}{\mathrm{Y}_{\mathrm{R}}}
$$

\subsection{Annual capacity factor:}

The capacity factor (CF) is defined as the ratio of the actual annual energy output $\mathrm{E}_{\mathrm{AC}}$ to the amount of energy the solar PV power plant would generate if it is operated at full rated power Pstc for $24 \mathrm{~h}$ per day for a year [23]

$$
\mathrm{CF}=\frac{\mathrm{E}_{\mathrm{AC}}}{\mathrm{P}_{S T C} \times 24 \times 365}
$$

\subsection{CO2 emission avoided:}

The production of $1 \mathrm{~kW}$ of energy using fossil fuels generates $0.6 \mathrm{~kg}$ of $\mathrm{CO}_{2}$ emissions to the atmosphere, $\mathrm{PV}$ panels make it possible to avoid this emission when they are used to generate the same amount of energy [30]. $\mathrm{CO} 2$ emission avoided by three different PV panels installed on the roof of FSBM during their operation was calculated and the most profitable panel in terms of environmental criteria in one-year period and in two years of operating was determined. 


\section{Performance analysis method}

To analyze the real performance of $5.94 \mathrm{KWp}$ grid-connected PV systems, we have collected data about energy production along 2 years (2015-2016) of 3 real PV panels located in Casablanca.

The assembled data of these two years were organized, analyzed and filtered in order to avoid possible deviations from normal behavior. All these steps allowed us to have the exact look of the graph showing the monthly average production of our systems that we will present in the results parts.

As it is known, the energy generated from photovoltaic (PV) panels depends usually on meteorological data at a given location, different sources of solar radiation data exist, but it is very interesting to discuss the strengths and weaknesses of each data source. For our case, we preferred the new (PVGIS)-Helioclim database because it includes the same time period of meteorological data (2015-2016) [31]. Figure 6 and 7 show the monthly meteorological data of Casablanca (tilted solar irradiation, ambient temperature and wind speed) generated from the software.

PVGIS is one of the several simulation tools which is developed to help engineers and researchers in the design, the performance assessment and the feasibility of solar PV power plants in worldwide. This system allows us to determine the real performance of our installation because it makes it possible to calculate long- term average values of the irradiation [32].

Therefore we combine the actual electrical production data collected from our systems and the meteorological data given by PVGIS which includes data from the same time period, to evaluate the performance of 5.94 KWp grid-connected PV module technology systems consisting of three technologies namely a-Si, pc-Si and $\mathrm{mc}-\mathrm{Si}$ for a 12 months period under Casablanca climate conditions.

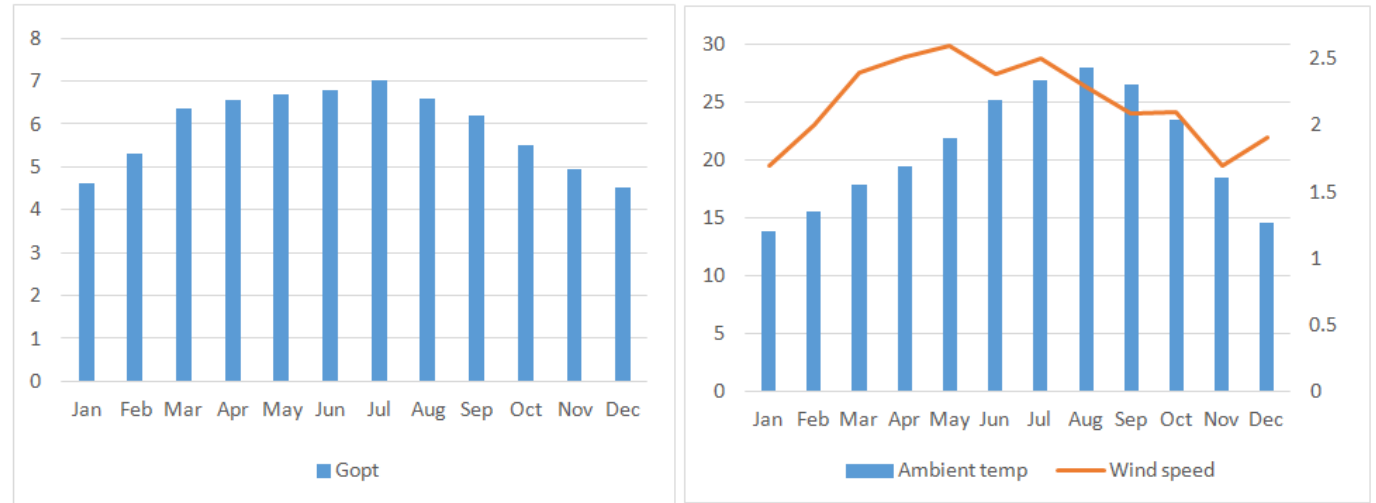

Figure 6:.Daily average radiation amount according to month Figure 7: Monthly average ambient temperature and wind speed

\section{Results and discussion}

In this part, the average monthly energy measurements for the two years, produced by three different types of PV systems installed on the roof of FSBM Casablanca is explained in details. Data produced were compared with each other and with their equivalents in the literature.

\subsection{Production analysis:}

After the integration of the instantaneous values of power on $5 \mathrm{~min}$ intervals, for two years of operation using equation (1) (Made by a monitoring system). Average monthly total electrical energy generated by PV systems is shown in Figure 8.

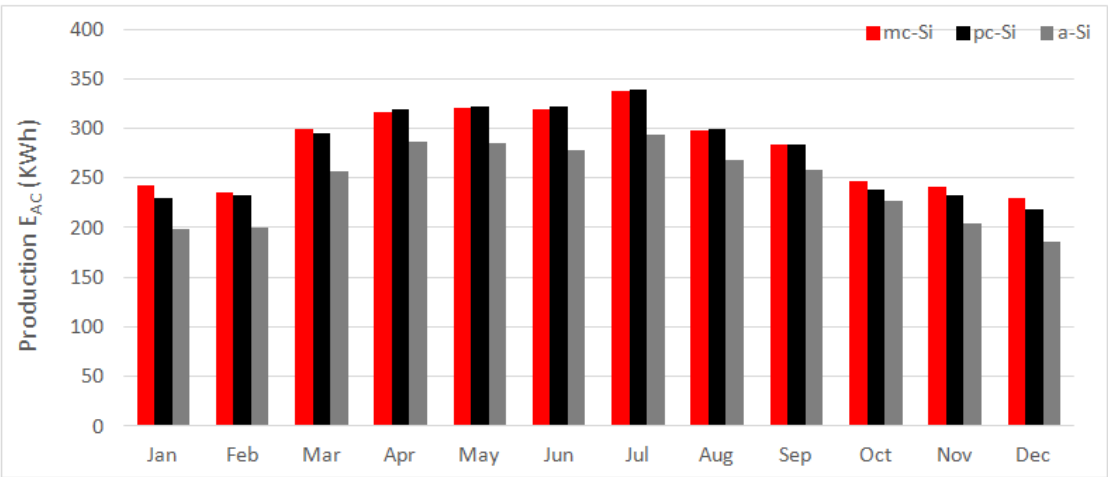

Figure 8: Harvested energy profile from the three-plant all year round. 
As can be seen, the month with the highest electric power production is July. But comparing annual sums of energy produced, indicates that the first installation constructed by a-Si panels generated $2941,15-\mathrm{kW} \mathrm{h}$, the second installation constructed by pc-Si panels generated $3331.15-\mathrm{kWh}$, and the third installation constructed by mc-Si panels generated $3370,89-\mathrm{kW}$ h annually. Total amount of energy generated by three plants is around 9643.19-kWh annually.

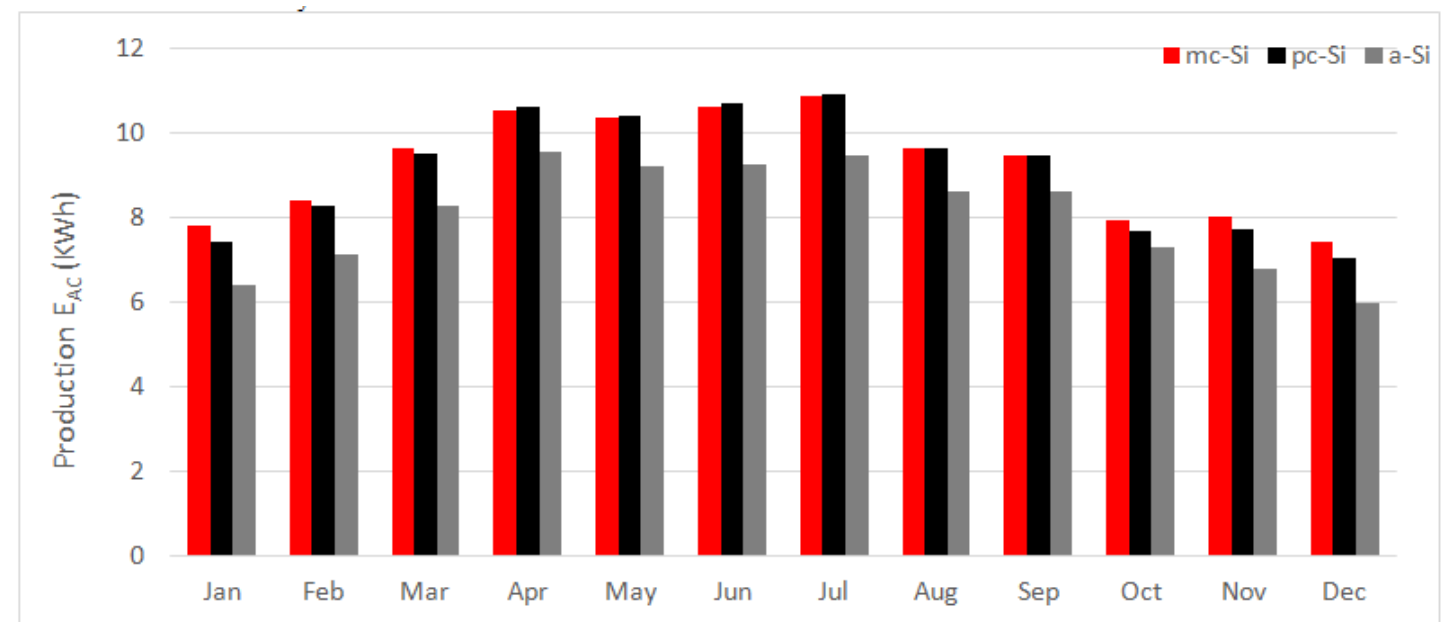

Figure 9: Monthly average of the daily AC electricity generated by the three PV systems.

Monthly average daily values of experimental output powers obtained from a-Si PV system with a total output power of $1860 \mathrm{~W}$, pc-Si PV system with a total output power of $2040 \mathrm{~W}$ and mc-Si PV system with a total output power of $2040 \mathrm{~W}$ according to datasheet are given in Figure 9. The system consisting of monocrystalline panels generated energy more than the other two panels during 7 months, polycrystalline during 5 months but the amorphous thin film panels always have less energy than the other two during the 12 months.

\subsection{System ef ficiency:}

Monthly energy conversion efficiencies of system were calculated with equation (2), and graphed in figure 10:

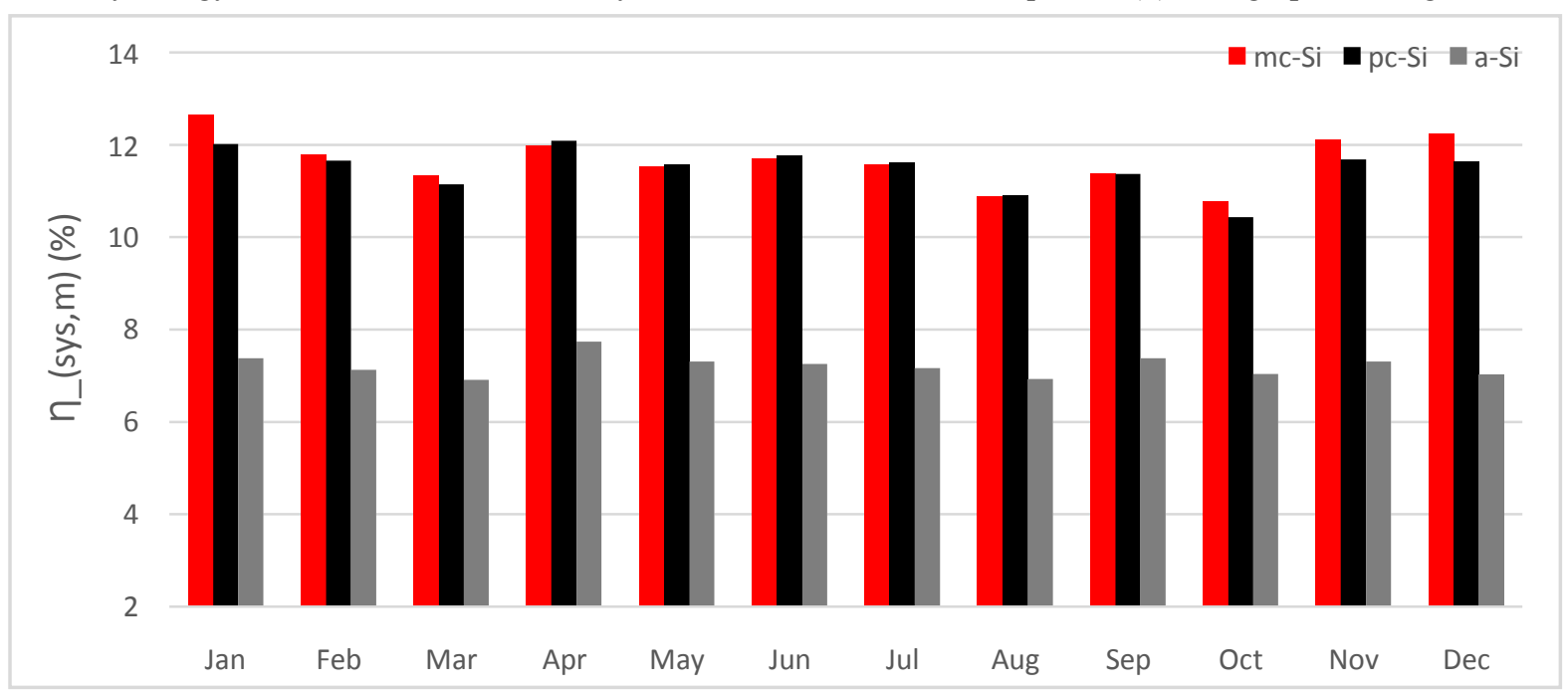

Figure 10: Monthly energy efficiency.

The maximum value of energy conversion efficiency for monocrystalline PV panels was about $12.66 \%$ in January and the minimum value was $10.77 \%$ in October. Although this value for polycrystalline panels increased to $12.08 \%$ in April, its efficiency remained at $11.4 \%$ during the whole year. The minimum value of energy conversion efficiency for a-Si PV panel was $6.91 \%$ and the maximum values was $7.74 \%$. Monthly average energy efficiency for the three technologies were $7.21 \%, 11.4 \%$ and $11.7 \%$ for a-Si, pc-Si and mc-Si PV panels, respectively. 


\subsection{Energy yields:}

Equations (4) and (5) were used to calculate our 12 monthly averages of daily final yields for the three above mentioned PV systems as well as the 12 reference which are considered simulated as long as $\mathrm{G}_{\mathrm{opt}}$ irradiation is obtained via PVGIS.

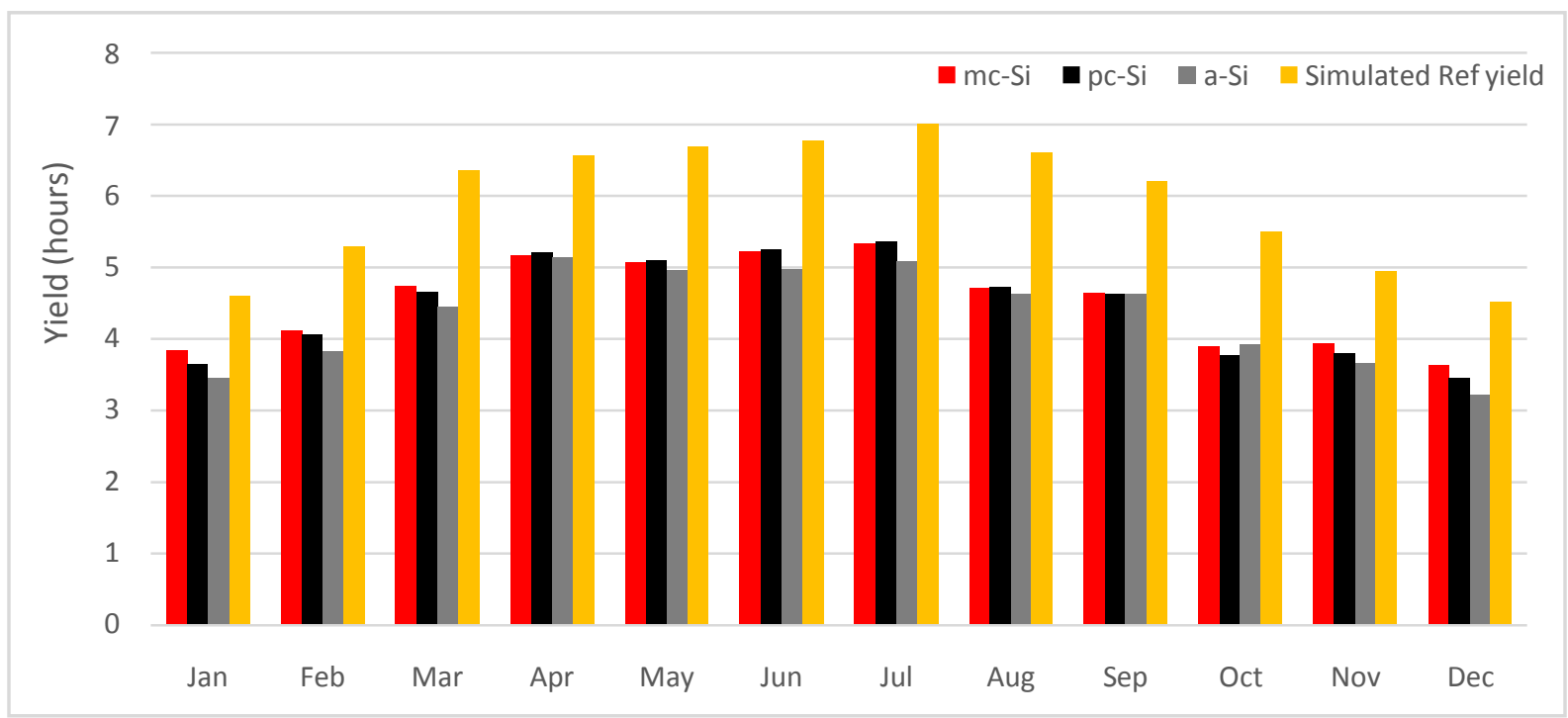

Figure 11: Final yields of the three PV systems compared with the simulated reference yield

The monthly average of the daily final yields YF varied from:

$\square 3.21$ to 5.14 hours, moving from December to April, for the a-Si plant.

$\square 3.45$ to 5.36 hours, moving from December to July for the pc-Si plant.

$\square 3.63$ to 5.33 hours, moving from December to July for the mc-Si plant.

When moving from December to July the reference yield $\mathrm{Y}_{\mathrm{R}}$ increased from 4.51 to 7.01 hours.

\subsection{Performance ratio:}

Performance ratio is a way to evaluate a relative efficiency of a PV system [21]. It is calculated using equation (6). The PR of 3 different PV panels are shown in Figure 12.

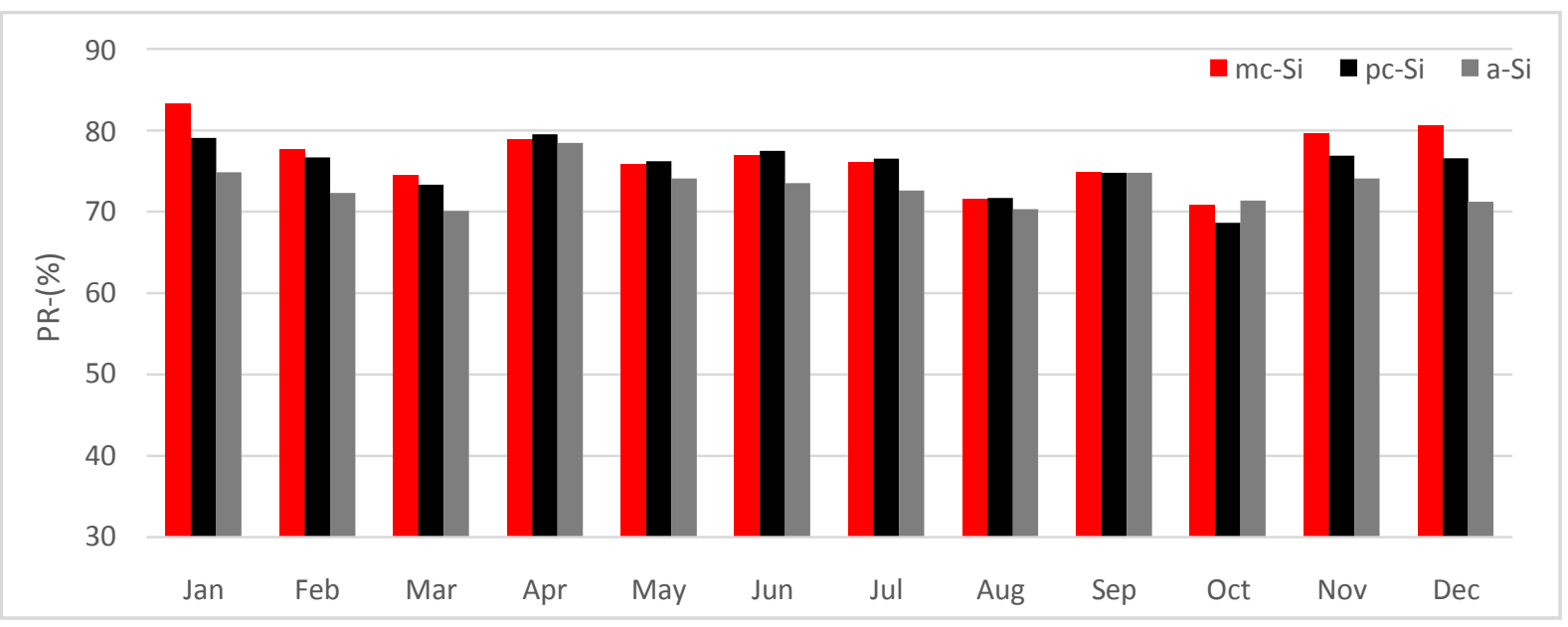

Figure 12: Performance ratios of the three PV systems

Pr of monocrystalline $\left(\operatorname{Pr}_{\mathrm{m}}\right) \mathrm{PV}$ panel's values change in range of 83.26\%-70.86\%. $\operatorname{Pr}_{\mathrm{m}}$ panels have better results in cold time. Yearly average value of monocrystalline Pr is determined by $76.7 \%$. Although the value of polycrystalline panel's PR (Prp) is resolved in range of 79.26\%-68.61\%, its PR can be more near- constant and have better results in summer time. $\mathrm{Pr}$ range of a-Si $\left(\mathrm{Pr}_{\mathrm{a}}\right) \mathrm{PV}$ panel values are determined in range of $78.44 \%$ 70.09\%. Average $\mathrm{PR}_{\mathrm{p}}$ and $\mathrm{Pr}_{\mathrm{a}}$ is respectively $75.6 \%, 73.1 \%$. 


\subsection{Effect of environmental temperature change on panel efficiency:}

To see the changes in efficiency of PV panel types towards environmental temperature, we have made a graph for the efficiency as a function of the ambient temperature evolution. The graph of the study is given in Figure

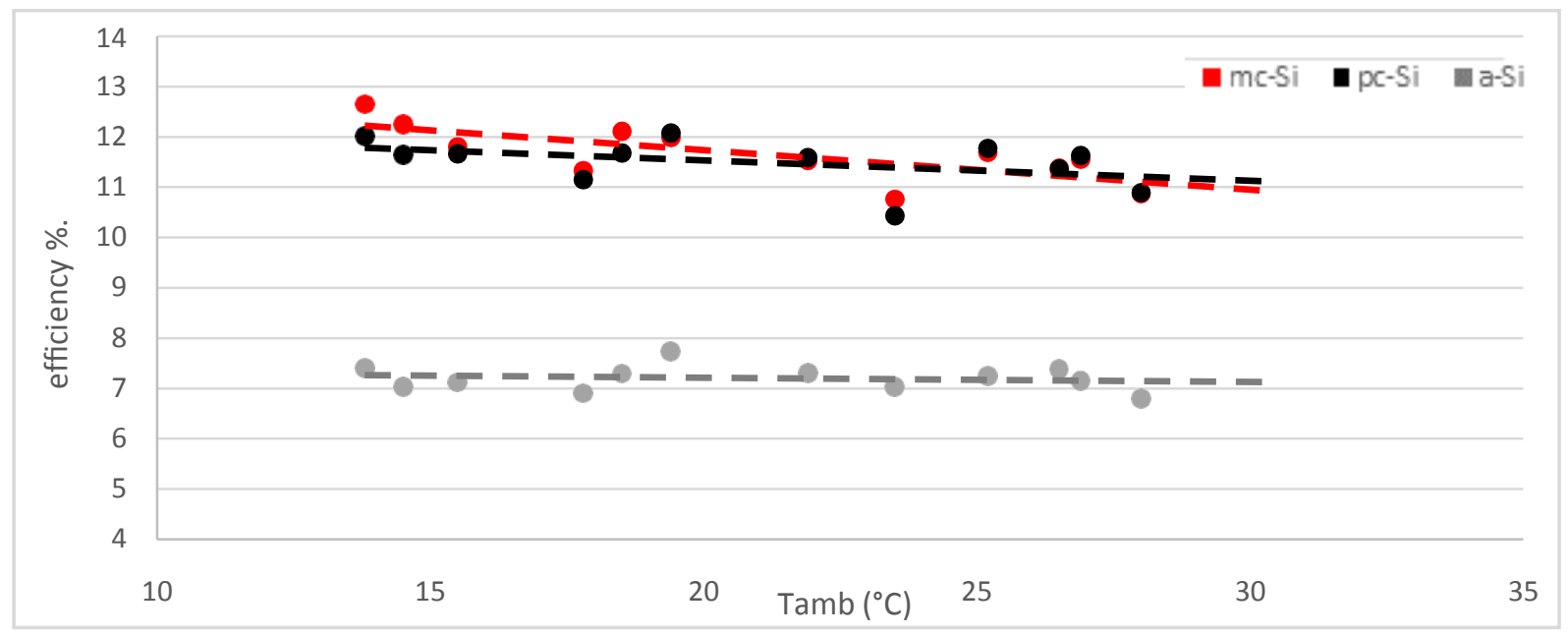

Figure 13: Relation between temperature and monthly efficiency.

As it is obvious from the graph and literature the ambient temperature has a negative effect on the efficiency, but the value of this effect depends on the type of panels. It is very interesting to discuss the reason why mc-Si panels have higher performance in cold time and $\mathrm{pc}-\mathrm{Si}$ in summer time under similar operating conditions. The TCP (Temperature Coefficient at Pmax) is a major justification which provides a measure of the decrease in produced power due to temperature increase. The TCP for the studied $\mathrm{mc}-\mathrm{Si}$ modules is $-0.45 \% /{ }^{\circ} \mathrm{C}$, for pc-Si modules, it is $-0.41 \% /{ }^{\circ} \mathrm{C}$ and it is $-0.28 \% /{ }^{\circ} \mathrm{C}$ for a-Si. Accordingly, the value of the TCP of pc-Si panels will lead to a more generated output power of pc-Si in summer time. Lower negative value of Amorphous TCP also justifies the behavior of the amorphous panels which is less affected by the temperature. But, globally the mc-Si presents higher performance compared to the other two panels in weather conditions of Casablanca city.

5.6. Effect of environmental radiation change on performance ratio:

A similar study was also made between performance ratios of PV panel types and the values of radiation. The graph of the study is given in Figure 14.

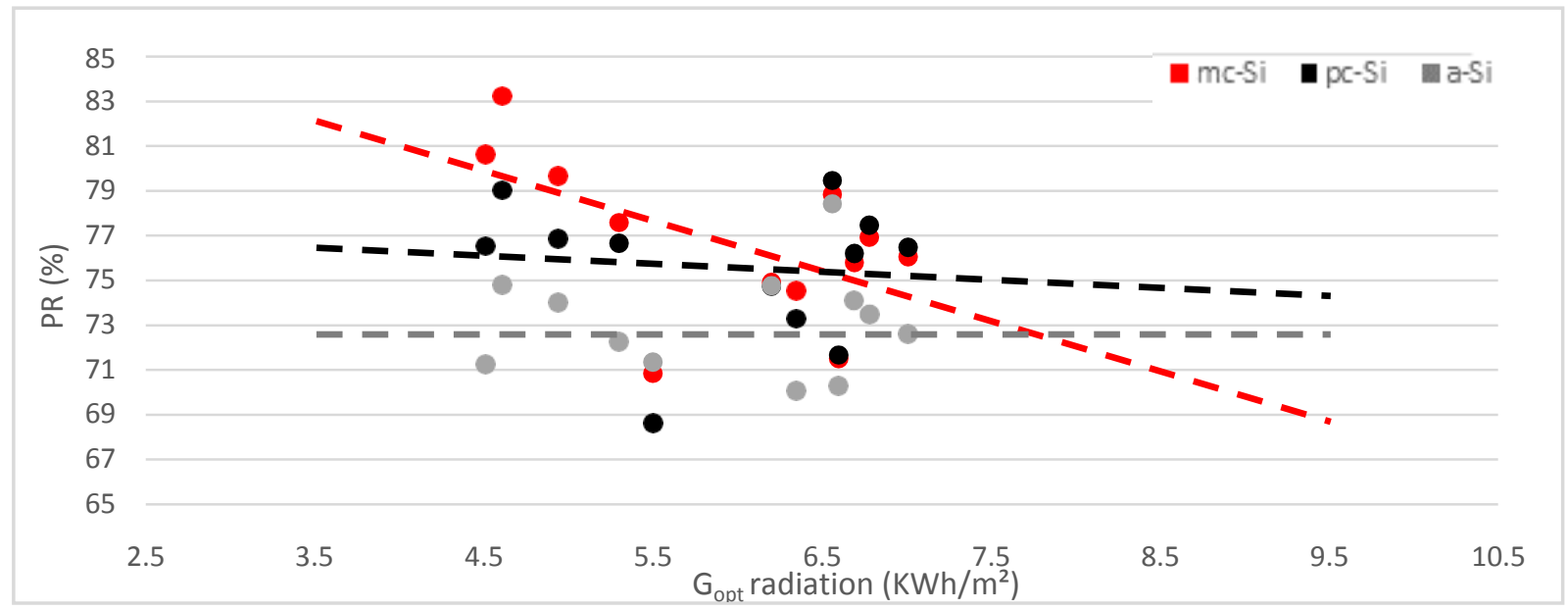

Figure 14: Relation between $P R$ and radiation

This graph shows how the change in the value of $G_{\text {opt }}$ influences $P_{R}$ values. Increase in the value of $G_{\text {opt }}$ affects $P_{R a}$ value positively, but $P_{R m}$ and $P_{R p}$ values negatively. For both monocrystalline and polycrystalline technologies, the increase in radiation gives an increase in temperature which gives a lower performance ratio but the amorphous which is less influenced by the temperature, irradiation allows it to increase its performance ratio. 


\subsection{Annual capacity factor:}

The annual capacity factor of the PV system were calculated using equation (7):

\begin{tabular}{|c|c|}
\hline Modules Types & Capacity factor (\%) \\
$\mathrm{mc}-\mathrm{Si}$ & $18.86 \%$ \\
\hline $\mathrm{pc}-\mathrm{Si}$ & $18.64 \%$ \\
\hline $\mathrm{a}-\mathrm{Si}$ & $18.05 \%$ \\
\hline
\end{tabular}

Table 3: Annual capacity factor for installed technologies

The annual results concerning the capacity factor are reported in Table 3. The results show that the mc-Si installation exhibits slightly higher value $\left(\mathrm{CF}_{\mathrm{m}}=18.86 \%\right)$ compared to $\mathrm{pc}-\mathrm{Si}$ and a-Si installations which have respective values $\left(\mathrm{CF}_{\mathrm{p}}=18.64 \%\right.$ and $\left.\mathrm{CF}_{\mathrm{a}}=18.05 \%\right)$

5.8. $\mathrm{CO}_{2}$ emission avoided:

The following table shows the amount of $\mathrm{CO}_{2}$ emissions avoided for one-year period and for the two years of operation.

\begin{tabular}{|c|c|c|}
\hline Modules Types & CO2 avoided for one-year (tons) & CO2 avoided for 2-years operation (tons) \\
\hline $\mathrm{mc}-\mathrm{Si}$ & 2.023 & 4.046 \\
\hline $\mathrm{pc}-\mathrm{Si}$ & 1.999 & 3.998 \\
\hline $\mathrm{a}-\mathrm{Si}$ & 1.765 & 3.530 \\
\hline
\end{tabular}

Table 4: $\mathrm{CO} 2$ emission avoided for installed technologies

As can be seen, mc-Si modules have the potential of reducing more $\mathrm{CO} 2$ emission than $\mathrm{pc}-\mathrm{Si}$ and a-Si modules. A total annual reduction of emissions of about 5.787 tons can be achieved by using electricity generated by PV systems instead of using fossil fuels.

\subsection{Comparison of performance with equivalent in literature:}

In order to draw a clear picture about the performance of the investigated solar PV installations, performance parameters were compared with their equivalents in the literature (see table 4).

\begin{tabular}{|c|c|c|c|c|c|}
\hline Location & PV type & $\begin{array}{l}\text { Capacity } \\
\text { (KWp) }\end{array}$ & $\begin{array}{c}\text { Performance } \\
\text { Ratio }\end{array}$ & $\begin{array}{c}\text { Overall } \\
\text { Efficiency }(\%) \\
\end{array}$ & Reference \\
\hline Dublin, Ireland & $\mathrm{mc}-\mathrm{Si}$ & 1.72 & 81.5 & 12.6 & [23] \\
\hline Island of Crete, Greece & $\mathrm{Pc}-\mathrm{Si}$ & 171.36 & 67.36 & - & [25] \\
\hline Khatkar-Kalan, India & $\mathrm{Pc}-\mathrm{Si}$ & 190 & 74 & 8.3 & [33] \\
\hline Eastern Cape, South Africa & $\mathrm{Pc}-\mathrm{Si}$ & 3.22 & 84 & - & [34] \\
\hline Poland & a-Si & 1 & $60-80$ & $4-5$ & [35] \\
\hline Casablanca, Morocco & a-Si & 1.86 & 73.1 & 7.21 & \multirow{3}{*}{$\begin{array}{l}\text { Present } \\
\text { Study }\end{array}$} \\
\hline Casablanca, Morocco & $\mathrm{Pc}-\mathrm{Si}$ & 2.04 & 75.6 & 11.4 & \\
\hline Casablanca, Morocco & $\mathrm{mc}-\mathrm{Si}$ & 2.04 & 76.7 & 11.7 & \\
\hline
\end{tabular}

Table 5: Performance comparison of different grid-connected PV systems in different locations

It is clear that the performances obtained in the present study are quite similar to the other installations, which makes it possible to prove the accuracy of our results.

\section{Conclusion}

The present paper investigates the performance analysis of $5.94 \mathrm{KWp}$ grid-connected PV systems installed on the roof of an administrative building at the Faculty of science Ben M'sik Casablanca (Morocco). Meteorological data of the site were derived from PVGIS database and by using real data of production for two years operation. Monthly and annual performance indicators were calculated and compared for the three installed technologies (Mc-Si, Pc-Si and A-Si). The main findings of this procedure are the followings:

$>$ As a result of 2 years-observation between January 2015 and December 2016, average total electrical energy generated by a-Si, pc-Si and mc-Si panels are $2941.15 \mathrm{KWh}, 3331.15 \mathrm{KWh}$ and $3370.89 \mathrm{KWh}$, respectively.

$>$ The annual overall efficiency of the PV system were, respectively, $7.21 \%$ in the case of a-Si installation, $11.4 \%$ in the case of pc-Si installation and $11.7 \%$ in the case of mc-Si.

$>$ The annual average daily final yields were $4.33 \mathrm{~h}, 4.47 \mathrm{~h}$ and $4.53 \mathrm{~h}$ for a-Si, pc-Si and mc-Si installations, respectively. 
> Average performance ratio of $1860 \mathrm{~W}$ a-Si panels, for $2040 \mathrm{~W}$ pc-Si and mc-Si panels was calculated as $73.1 \%, 75.6 \%$ and $76.7 \%$, respectively.

$>$ When changes in panel energy conversion efficiency according to temperature were examined and also the changes in performance ratio according to radiation. The real behaviors for each panels has been brought to light.

$>$ The annual capacity factor of the PV system were, respectively, $18.05 \%$ in the case of a-Si installation, $18.64 \%$ in the case of pc-Si installation and $18.86 \%$ in the case of mc-Si.

Dach $1 \mathrm{~kW}$ electric power generated by PV panels decreases to $0.6 \mathrm{~kg} \mathrm{CO} 2$ emissions in the atmosphere. Due to PV systems installed on the basis of this fact, it was calculated that 5.787 tons $\mathrm{CO} 2$ emission was reduced in a year. 1.765 tons of this decrease was ensured by a-Si panels, 1.999 tons by pc-Si panels and 2.023 tons by mc-Si panels.

\section{Acknowledgment}

All the authors as well as all the rest of the-PROPRE.MA\| partner are grateful to IRESEN for financing this study and would like to thank all the IRESEN staff for their support.

\section{References}

[1]. Bymap. World energy consumption n.d http://world.bymap.org/ElectricityConsumption.html

[2]. http://www.mem.gov.ma/SiteAssets/Monographie/DirectionsCentrales/DEREE.pdf

[3]. Kalogirou Soteris A. Solar Energy Engineering: Processes and Systems. Amsterdam, Netherlands: Elsevier; 2014.

[4]. El Fathi Amine, Nkhaili Lahcen, Bennouna Amin, Outzourhit Abdelkader.Performance parameters of a standalone PV plant. Energy Convers Manage 2014;86:490-5.

[5]. Rawat Rahul, Kaushik SC, Lamba Ravita. A review on modeling, design methodology and size optimization of photovoltaic based water pumping, standalone and grid connected system. Renew Sustain Energy Rev 2016;57:1506-19.

[6]. International Energy Agency (IEA), Technology Roadmap Solar Photovoltaic Energy, 2014. www.iea.org

[7]. Zhao J, Wang A, Green MA. Prog Photovolt: Res Appl 1999;7:471.

[8]. Zhao J, Wang A, Green MA. $19.8 \%$ efficient honeycomb textured multi-crystalline and $24.4 \%$ monocrystalline silicon solar cells. Appl Phys Lett 1998;73:1991-3.

[9]. Matsui T, Sai H, Suezaki T, Matsumoto M, Saito K, Yoshida I, Kondo M. Development of highly stable and efficient amorphous silicon based solar cells. Proc. $28^{\text {th }}$ European Photovoltaic Solar Energy Conference, 2013; 2213-2217.

[10]. Durisch W, Tille D, Wörz A, Plapp W. Characterisation of photovoltaic generators. Appl Energy 2000;65(1-4):273-84

[11]. Li DHW, Cheung GHW, Lam JC. Analysis of the operational performance and efficiency characteristic for photovoltaic system in Hong Kong. Energy Convers Manage 2005;46(7,8):1107-18.

[12]. Ghiani Emilio, Pilo Fabrizio and Cossu Silvestro -Evaluation of photovoltaic installations performances in Sardiniall Energy Conversion and Management, Volume 76, December 2013, Pages 1134-1142

[13]. Adel Mellit and Alessandro Massi Pavan -Performance prediction of $20 \mathrm{kWp}$ grid-connected photovoltaic plant at Trieste (Italy) using artificial neural network\| Energy Convers Manage, Volume 51, Issue 12, December 2010, Pages 2431-2441.

[14]. Emmanuel Kymakis, Sofoklis Kalykakis and Thales M. Papazoglou.-Performance analysis of a grid connected photovoltaic park on the island of Cretell Energy Convers Manage. Volume 50, Issue 3, March 2009, Pages 433-438.

[15]. Diego Micheli, Stefano Alessandrini, Robert Radu and Iosto Casula -Analysis of the outdoor performance efficiency of two grid connected photovoltaic systems in northern Italy\| Energy Convers Manage. Volume 80, April 2014, Pages 436-445

[16]. Danny H.W. Li, K.L. Cheung, Tony N.T. Lam an Wilco W.H. Chanl A study of grid-connected photovoltaic PV system in Hong Kongll. Applied Energy. Volume 90, Issue 1, February 2012, Pages 122-127

[17]. Cañete C, Carretero J, Sidrach-de-Cardona M. Energy performance of different photovoltaic module technologies under outdoor conditions. Energy 2014;65:295-302.

[18]. N. Aarich, N. Erraïssi, M. Akhsassi, A. Lhannaoui, M. Raoufi and A. Bennouna. -Propre.Mall project: roadmap \& preliminary results for gridconnected PV yields maps in Morocco. IEEE International Renewable and Sustainable Energy Conference (IRSEC) 2014; 774-777.

[19]. Bhattacharjee S, Bhakta S. Analysis of system performance indices of PV generator in a cloudburst precinct. Sustain Energy Technol Assess 2013;4:62-72.

[20]. IEC. Photovoltaic system performance monitoring - guidelines for measurement, data exchange, and analysis IEC Standard 61724 . Geneva, Switzerland; 1998.

[21]. A. Guenounou, A. Malek, M. Aillerie. Comparative performance of PV panels of different technologies over one year of exposure: Application to a coastal Mediterranean region of Algeria. Energy Conversion and Management 114 (2016) 356-363.

[22]. Mustafa E. Basoglu, Abdulvehhap Kazdaloglu, Tarik Erfidan, Mehmet Z. Bilgin, Bekir Çakir. Performance analyzes of different photovoltaic module technologies under Izmit, Kocaeli climatic conditions. Renewable and Sustainable Energy Reviews 52 (2015) $357-365$.

[23]. L.M. Ayompe, A. Duffy, S.J. McCormack, M. Conlon. Measured performance of a $1.72 \mathrm{~kW}$ rooftop grid connected photovoltaic system in Ireland. Energy Conversion and Management 52 (2010) 816-825.

[24]. Adaramola, M., Vagnes, E., 2015. Preliminary assessment of a small-scale rooftop PV grid tied in Norwegian climatic conditions. Energy Convers. Manage. 90, 458-465.

[25]. Kymakis, E., Kalykakis, S., Papazoglou, T.M., 2009. Performance analysis of a grid connected Photovoltaic Park on the island of Crete. Energy Convers. Manage. 50 (3), 433-438.

[26]. Al-Otaibi, A., Al-Qattan, A., Fairouz, F., \& Al-Mulla, A. (2015). Performance evaluation of photovoltaic systems on Kuwaiti schools' rooftop. Energy Conversion and Management, 95, 110-119.

[27]. Marion, B., Adelstein, J., Boyle, K., Hayden, H., Hammond, B., Fletcher, T., et al. (2005, January). Performance parameters for gridconnected PV systems. In Photovoltaic Specialists Conference, 2005. Conference Record of the Thirty-first IEEE (pp. 1601- 1606). IEEE. 
[28]. A.Allouhi, R.Saadani, T.Kousksou, R.Saidur, A.Jamil, M.Rahmoune, Grid-connected PV system installed on institutional buildings:Technology comparison, energy analysis and economicperformance, Energy and Buildings http://dx.doi.org/10.1016/j.enbuild.2016.08.054

[29]. Rehman S, El-Amin I. Performance evaluation of an off-grid photovoltaic system in Saudi Arabia. Energy 2012;46:451e8.

[30]. Kato K, Murata A, Sakuta K. Energy pay-back time and life-cycle CO2 emission of residential PV power system with silicon PV module. Prog Photovolt 1998;6:105-15.

[31]. European Commission. PVGIS: PV Potential Estimation Utility, Photovoltaic Geographical Information System. http://re.jrc.ec.europa.eu/pvgis/apps4/pvest.php?lang=en\&map=africa

[32]. Huld, T., Cebecauer, T., Súri, M. and Dunlop, E.D. (2010) Analysis of One-Axis Tracking Strategies for PV Systems in Europe. Progress in Photovoltaics: Research and Applications, 18, 183-194.

[33]. Sharma, V., \& Chandel, S. S. (2013). Performance analysis of a $190 \mathrm{kWp}$ grid interactive solar photovoltaic power plant in India. Energy, 55, 476-485.

[34]. Okello, D., van Dyk, E. E., \& Vorster, F. J. (2015). Analysis of measured and simulated performance data of a $3.2 \mathrm{kWp}$ grid- connected PV system in Port Elizabeth, South Africa. Energy Conversion and Management, 100, 10-15.

[35]. Pietruszko SM, Gradzki M. Performance of a grid connected small PV system in Poland. Appl Energy 2003;74:177-84. http://dx.doi.org/10.1016/S0306-2619 (02)00144-7. 